\title{
合成ゲノムで人工細菌を作製
}

\section{Synthetic genome resets biotech goals}

Alla KATSNELson 2010 年 5 月 27 日号 Vol. 465 (406)

www.nature.com/news/2010/100526/full/465406a.html

合成ゲノムで近縁生物種の細胞を「再起動」させることに成功し、 自己複製可能な人工細菌が作製された。

合成生物学は、人間の要求に応えて生 物の構成単位を設計し直すという、大 胆な目標を掲げる研究分野であり、究極 的には実用性が高いと考えられる。また 一方では、自然の生物」対「人工生命体」 という明快な定義に挑む試みでもある。

2010 年 5 月、人工的に合成した細菌 のゲノムを近縁な別種の細菌細胞に移植 して「乗っ取り」に成功したことが発表 された ${ }^{1}$ 。これは研究者たちが大いに待 ち望んでいたものであり、使われた技術 は従来よりもかなり大規模にゲノムを操 作できる。「この技術は、ゲノムを完全 に設計し直すという究極の目標の達成 に、重要なものだと思います」と、マサ チューセッツ工科大学（米国ケンブリッ ジ）の合成生物学者 Ron Weiss は話す。

今回、 $\mathrm{J} ・$ クレグ・ベンター研究所 (米国メリーランド州ロックランド) の Daniel Gibson たちは、マイコプラズマ という細菌の一種 Mycoplasma mycoides から得た高精度のゲノム塩基配列を出 発点にした。これを鋳型として、それぞ れ約 1000 塩基対の長さの「カセット」 とよばれる短鎖 DNA のセットをDNA シーケンシングサービス会社に発注し、 作製された「カセット」を酵母細胞に入 れた。すると、酵母がもつ遺伝機構によつ てカセットがつなぎ合わされ、天然の マイコプラズマゲノムの合成コピーがで きる。最終的に、できあがつた 110 万 塩基対の合成ゲノムを、M. mycoides の 近縁種 Mycoplasma capricolum に移植し た。作製された新しい細胞ではゲノムだ
けが「特注品」だが、研究チームはこの 細胞を「人工細胞」とよんだ。なぜなら、 M. mycoides の特徵を示す分子構成がす ぐさま現れたからである。「染色体を入 れ替えることで、別種の細胞へと完全に 変化したのです」VVenter は 5 月後半の 記者会見で、こう述べている。

ここに至るまで、研究チームはさまざ まな障害にぶつかつた。プロジェクトの 最終段階では、合成ゲノムを移植すると 細胞が死んでしまう事態に陥つた。染色 体複製にかかわる 1 個の遺伝子で塩基 対が 1 つ欠失していたことが原因だっ た。この問題を解決し最終的にできた合 成ゲノムはしっかり機能し、レシピエン ト細胞は生存能力があり自己複製できる 細菌へと形質転換しており、合成 DNA がコードするさまざまな形質を示した。

この技術は、画期的なエネルギー生成 法の開発や、環境モニター用の新規セン サーの実現、医薬品量産用の「細菌工 場」の構築などへの応用が考えられる。

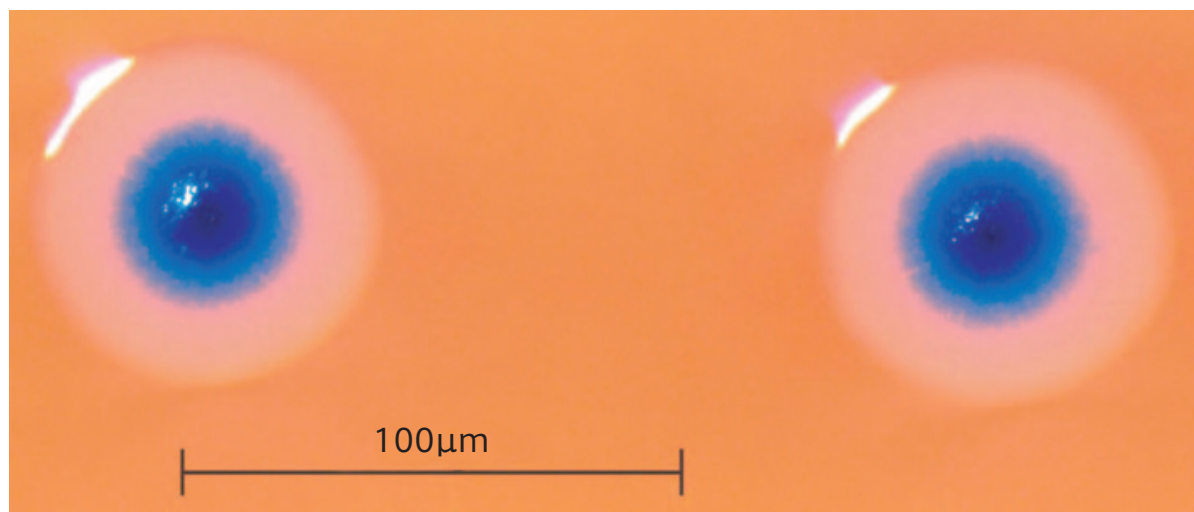

化学マーカーで青色に見えているのは、合成ゲノムを入れた細胞から作られたコロニー。
次の課題は、遺伝子回路の組み立て方を 会得することだろう。つまり、互いに複 雑に相互作用する一群の遺伝子を人工的 につなげて、必要な形質が現れるように することである。今までのところ、約 1 万 $5000 \sim 2$ 万 5000 塩基対の遺伝子回 路であれば確実に設計できる。この程度 の長さの塩基配列には、拈よそ $6 \sim 10$ 個の遺伝子プロモーターが入る。しかし Weissによれば、これより長い塩基対の 場合どんな遺伝子回路でも、「現時点で はちゃんと機能するような設計はできな いでしょう」という。必要な形質がさら に多数の遺伝子によって制御されている 場合、その特徵を明確に定義付けること は難しく、また、こうした遺伝子群を組 み合わせて単一回路にすることはさらに 難しいのだ。「新しく組み合わせた複数の 遺伝子を一緒に機能させることは、実際 にはかなりの難題なのです」と彼はいう。

Weiss は、この課題は最終的には達成 できると確信していると話す。しかしな がら、すべての研究者が、自然のゲノム を単に修正変更するよりも、こうした遺 伝子回路を合成ゲノム内に組み込むほう が効率がよいと思っているわけではな い。ハーバード大学 (米国マサチュー セッッ州ボストン）の遺伝学者 George Church は、Weiss の意見に賛同してい る。「ただ、合成生物学に対して、全ゲ ノム合成を望むのか、それとも、変化さ せたい部分を合成するだけでいいのか、 その結論はまだ出ていないと思います」 と彼はいう。 
一部の監視団体は、塩基配列データの みを使って生物を再構成することができ れば、バイオテロリストも実験室で有害 な微生物を合成できるようになるおそれ があると懸念している。しかし、それに は技術的にかなり高度な技能が必要だ ろう。スタンフォード大学 (米国カリ フォルニア州) の生命倫理学者 Mildred Cho によると、もつと起こりうる確率 が高い問題は、実験室で作り出された生 物が偶発的な事故で外部に流出してしま うことだという。そのため、ベンター研 究所チームのように、人工生物と天然の 生物を識別する「透かし」DNA 配列を 組み込むことが絶対に必要となる。米国 のバラク・オバマ大統領は、今回の発表 を受けて生命倫理諮問委員会を設置し、
この研究の影響を調査して 6 か月で報 告書を提出させる予定である。

この技術は、実用性があるだけでな く、生物学の基本的な疑問の追求も可 能にする。その中には、どれくらいの 数の遺伝子があれば細胞は生存できるの か、という疑問も含まれる。そして、そ うした最小限の遺伝子をもつゲノムを合 成することは、Venterの長年の目標の 1つでもあるのだ。カリフォルニア大 学サンフランシスコ校の合成生物学者、 Christopher Voigt は、ゲノム合成と人 工細胞作製の技術はいずれ、絶滅生物を 復活させたり、塩基配列を保存するだけ で種多様性の目録を作ったりできるとこ ろまで行くのではないかと話す。 その実現はまだ遠い先の話だ。現在、
全ゲノムの塩基配列を解読できる研究 室はほとんどないし、Gibson や Venter たちも単純な生物を対象にした研究し か行えない。研究チームは、酵母の細 胞内機構を利用して合成ゲノムを構築 したが、酵母では最大の染色体でもわ ずか約 200 万塩基対しかなく、もつと 長いゲノムの構築には使えそうにない。 「しかし、200 万塩基対でも価值があり ます。この長さは確実に実現可能です し、このくらいの大きさのゲノムにお さまる有用な細菌はたくさんいますか ら」と Gibson は話す。

(翻訳：船田晶子)

1. D. G. Gibson et al. Science 329, 52-56 (2010). 